\title{
TRADITIONAL FORMS AND GENRES OF TURKISH MUSIC IN THE CREATIONS OF INTERNATIONAL ART MUSIC COMPOSERS OF TURKEY*
}

\author{
Türk Uluslararası Sanat Müziği Bestecilerinin Eserlerinde Türk \\ Müziğinin Geleneksel Türleri ve Biçimleri
}

Özge USTA ${ }^{* *}$

\begin{abstract}
$19^{\text {th }}$ century was an era of nationalist movements in music. Nationalism was seen in important regions of the world, especially in Russia and Northern Europe. These nationalistic movements affected international art music composers of Turkey in the early years of Turkish Republic. Generally Turkish composers preferred to use traditional folk music elements instead of the elements of traditional art music. Either folk music with its melodic characteristic or maqam structure of art music is used by many international Turkish composers after the Turkish Fives. Generally, maqam factors are used as building stones in the compositions. The genre has been the less mentioned subject than maqam regarding the reflection of tradition. Besides, it is seen that the forms and genres of folk music are used in international art music. Here I present the composers' preferences regarding Turkish music genres with notation samples.
\end{abstract}

Keywords: Turkish traditional forms, Turkish traditional genres, Turkish international art music composers, Turkish traditional music, Turkish fives.

ÖZ

19. yüzyıl, müzikte ulusalcı hareketlerin görüldüğü dönemdi. Ulusalcılık dünyanın önemli bölgelerinde özellikle Rusya ve Kuzey Avrupa'da görülmüştü. $\mathrm{Bu}$ ulusalcı hareketler Türkiye Cumhuriyeti'nin ilk dönemlerindeki uluslararası sanat müziği bestecilerini etkilemişti. Türk bestecileri genellikle, geleneksel sanat müziği unsurları yerine geleneksel

Araştırma Makalesi Geliş Tarihi: 03.05.2018 Kabul Tarihi: 11.06.2018

* Yasar International Music Theory Conference'ta gerçekleşen basılmamış, sözlü sunumun genişletilmiş versiyonudur.

** Doç. Dr., Yaşar Üniversitesi Sanat ve Tasarım Fakültesi Müzik Bölümü, Selçuk Yaşar Kampüsü Üniversite Caddesi No 37-39 Bornova-İzmir ozge.usta@yasar.edu.tr

ORCID ID: https://orcid.org/0000-0003-2766-8193 
halk müziği unsurlarını kullanmayı tercih etmişti. Türk Beşleri’nden sonraki Türk besteciler, halk müziğinin melodik yapısının yanında geleneksel sanat müziğinin makamsal yapısını ve makamsal unsurları genellikle müzikteki yapı taşları olarak kullanmıştı. Tür, geleneğin yansımasıyla ilgili olarak makamdan daha az bahsi geçen bir konu olmuştu. Bunun yanısıra halk müziğinin biçimlerinin ve türlerinin uluslararası sanat müziğinde kullanıldığ1 görülmekteydi. Bu çalışmada bestecilerin Türk müziğgi türleriyle ilgili tercihleri notasyon örnekleriyle sunulmuştur.

Anahtar Kelimeler: Geleneksel Türk müziği biçimleri, geleneksel Türk müziği türleri, geleneksel Türk müziği, Türk Beşleri, Türkiye'nin uluslararası sanat müziği bestecileri.

\section{INTRODUCTION}

Anatolia hosted Hittites, Persians, Greeks, Romans, Byzantines, Seljuk Turks, Ottoman Turks and Republic Turks in the known history. Different religions are seen such as Shamanism, Christianity and Islam in this culture. Each civilization left different residues behind. The traditions of Central Asian originating Turks had an important place in the Anatolian music culture; the drum varieties used in the Shaman ceremonies and the military music groups called "Tuğ" were transformed to "Mehter" during Ottoman era. The western musicians were interested in "Mehter", "Mevlevi Music" and "Traditional Turkish Art Music". In the first quarter of the eighteenth century, military bands were founded in Anatolia following the reforms of Europe after removal of Mehterhane with Janissary army (Aydın 2003:13). Afterwards, identity seeking of the composers came to an order via start of Republic era in the field of international art music. At this point, it will be useful to mention briefly about the genres of traditional Turkish music. The traditional Turkish music is divided into two separate branches as "folk music" and "art music". Furthermore, the Turkish composers produced important compositions in the field of international art music. In this article, I will make evaluations about traditional Turkish music forms and genres utilized in the works of international Turkish composers.

Folk music is specific to the essence of nations (Sözer 2005: 323). Central Asian traditions take the first place in the roots of Turkish folk music, which depends on oral traditions. This genre spread via especially "âşıklı geleneği” (minstrelsy tradition). Creators and carriers of folk music have taken their music experiences with various characteristics to Anatolia and Balkans.

The melodic structure in folk music is modal as in traditional art music. 
Modal means maqam music here. In addition, the enormous number of repertoire is in "Hüseyni" maqam (Aydın 2003:15). Turkish folk music is seen in two forms: "vocal music" and "instrumental music". The researchers divide this genre according to its rhythm factor as kırıkhava (türkü-karşılama-deyişhalay-nefes-horon-ilahi-bar-hora-bengi-zeybek-semah-teke zorlatmast etc.) and uzun hava (hoyrat-maya-bozlak-elezber-müstezat-barak havalarl-divan-gurbet havalarl-ăglt etc.). Kırıkhavas are written and limited in measures, however, uzun havas have been evaluated as the extracts of folk music based on recitative performance and singing in rhythmical free style. Turkish folk music is performed as heterophonic in the company of various musical instruments (Sözer 2005: 323). Besides, endemic differences are observed in folk music. The musical instruments used in folk music are baglama, davul, zurna, kaval, sipsi, kabak kemane, Karadeniz kemençesi and tulum in general.

Another national music branch is Turkish art music in Turkey. According to the first of two different ideas about the root of the traditional art music, this genre of music is formed via the effects of Arabian and Persian cultures because of the religion union with the Ottoman Culture and the Anatolian local culture (Aydin 2003:15). According to the second idea, the music was brought to Arabia and Iran by Turks; in the books called La Musique Arabe (Arabian music) by Baron d'Erlanger, Kitab-ı Musıkî by Farabi and Kitabü'ş-Şifa by İbn-i Sina, which talks about Turkish music while mentioning about the music in Arabia. On the other hand, researchers are seeking the roots of traditional Turkish music in ancient Greek music or Byzantium music. However, it is clearly observed that the Turkish music gradation system does not overlap with the gradation system of these civilizations. According to the book called Kitabü'l Edvar by Safiyüddin Urmevî written in $13^{\text {th }}$ century, there is proof for the existence of music tradition with rules starting in Turkish civilizations at least as this century (Özkan 2003: 26).

The formal structure in Turkish art music is modal, that is maqam music, in melodic structure and it is divided into two forms as "instrumental music" and "vocal music" as in folk music. The vocal music is examined as religious and non-religious music. No musical instrument is used during performance of religious music at the mosques; however, the instrument accompaniment is suitable to the beliefs of the mysticism to the human sound (Aydin 2003:16). The most encountered religious genres are ayin, na't, durak, miraciye, ilahi, şugûl, ezan, mahfel sürmesi, tekbir, salât, münacat and mevlid. The widely known genres from secular music are kâr, kâr-nâtık, kârçe, beste, ăgır semâ,, yürük semaî, gazel, şarkı and köçekçe. The still vital genres of instrumental 
music are taksim, peşrev, medhal, saz semaisi, longa, sirto, oyun havast, aranağme (Özkan 2003: 96-97).

All of the Turkish art music genres mentioned have strong relations with the special rhythm patterns called "usûl". The usûls are ornamented with traditional variations called "velvele" by percussive instruments while accompanying to compositions. Ney, kanun, ud, tambur, classical kemençe, bendir, def, sol clarinet, kudüm and violin family members are mostly used in the present day.

In particular, let us talk about the usage of these traditional genres in the international art music works of well-known Turkish composers. There are some preparative elements of this process. The reforms were made in Republic of Turkey after announcement of Republic in 1923; various facultative young people and children from Turkey were sent to Europe to obtain composition and performance education as part of the music reform studies. The five composers called as The Turkish Five: Cemal Reşid Rey, Hasan Ferid Alnar, Ulvi Cemal Erkin, Ahmed Adnan Saygun and Necil Kazım Akses (Aydin 2003:19), commonly aimed to be the pioneers to create a new music genre by combining traditional Turkish folk and art music's rhythm and melody wealth with Western methods and techniques to benefit from new methods in developing international art music culture (Sözer 2005:713). Nineteenth century is the era where "nation" conscious movements are observed. Among these movements, Scandinavian, Spanish, Czech, Hungarian, Russian, Polish and Turkish trends exist. Since 1923 many various compositions have been composed in parallel or beyond line of Turkish Fives and still continue to be composed.

\section{The Main Turkish Music Genres Used by the International Art Music Composers in Turkey}

Either folk music with its melodic characteristic or maqam structure of art music is used by many international Turkish composers after the Turkish Fives. Generally, maqam factors are used as building stones in the compositions. "Aksak" usûls (5/8-7/8-9/8-10/8) which reflect the folk music characteristic are mostly preferred than traditional art music regarding the rhythm characteristics. I need to emphasis that the usûls in traditional Turkish music are the first characteristic, which discriminates the genres.

The genre has been the less mentioned subject than maqam regarding reflection of tradition. Besides this, it is seen that the forms and genres of folk music are used in international art music below: 


\section{Zeybek}

Zeybek from kırıkhava genre is specific to Aegean region; its measure is $9 / 4$ or $9 / 8$. Zeybek is seen in the compositions of the international Turkish composers to be mentioned.

- Necil Kazım Akses 1. String Quartet, 2. Movement

- Hasan Ferid Alnar Üç Oyun Havası, 2. Movement Zeybek for orchestra

- Cemal Reşid Rey Zeybek Opera; Turkish Scenes for Piano (Yürük Zeybek- Ağır Zeybek)

- Ulvi Cemal Erkin Lullaby-Improvisation-Zeybek for piano

- Ahmed Adnan Saygun Ağır Zeybek for violin and piano

- İlhan Baran Dört Zeybek for bass and piano; Zeybek from Three Abstract Dances for piano;

- Ferit Tüzün Inspirations for orchestra (Ağır Zeybek)

Traditional Zeybek sample is shown in Figure 1:

\section{YAĞCILAR ZEYBEĞI Izmir}
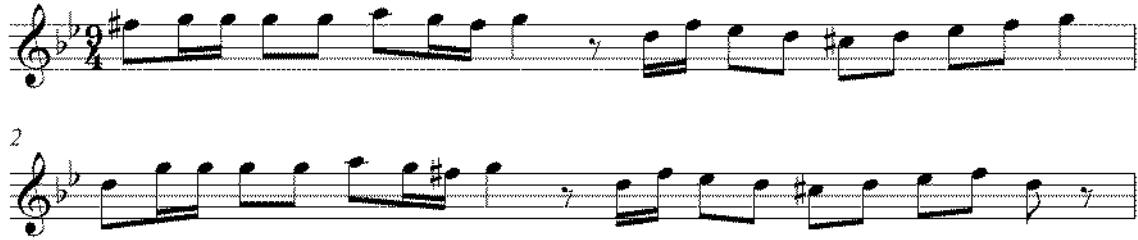

3

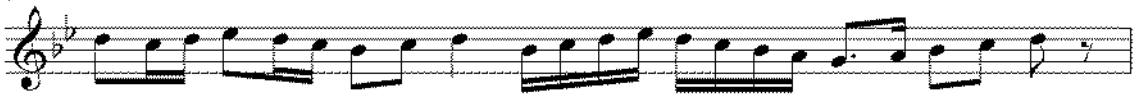

4

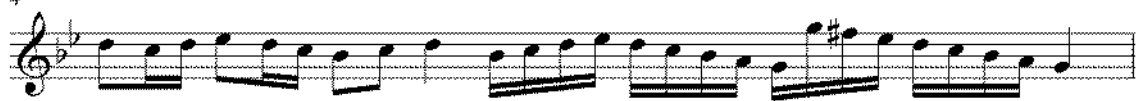

Figure 1: Traditional Zeybek Sample (turkuler.com, 01.06.2017)

The usage of Zeybek genre by Ferit Tüzün, one of international Turkish composers, is shown in Figure 2:

\section{Horon}

Horon from kırkkhava genre is a dance from the Black Sea region and it is seen in the compositions of the following international Turkish composers. 
- Ahmed Adnan Saygun Horon for violin and piano; Suite for orchestra Op. 14, 3. Movement Horon; Horon for piano; Horon for clarinet and piano

- Özkan Manav Horon for violin

- Cenan Akın Horon for piano

- Ferit Tüzün Anatolian Suite for orchestra, 2. Movement Horon

- Muammer Sun Yurt Renkleri for piano, 4. Movement Horonumsu

Traditional Horon sample is shown in Figure 3:

ESINTILER

\section{Zeybek}

Fertił Tüxüin

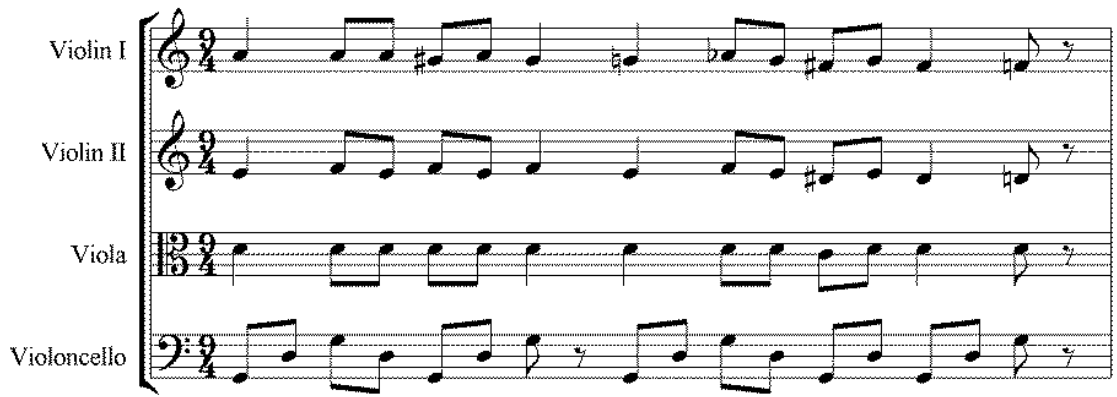

Figure 2: Ferit Tüzün Inspirations for Orchestra (Esintiler) 2. Ağır Zeybek (Şenel 2006: 46)

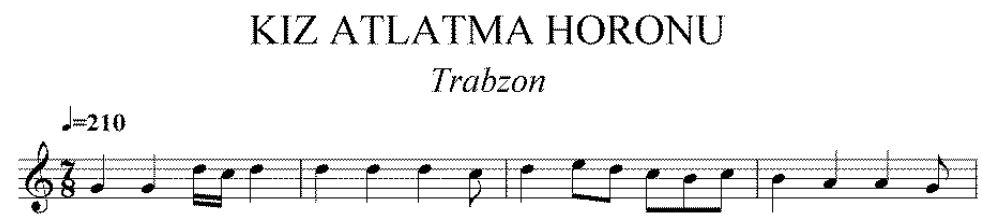

Figure 3: Traditional Horon Sample (turkuler.com, 01.06.2017)

The usage of Horon genre by Muammer Sun, one of international Turkish composers, is shown in Figure 4:

Muammer Sun

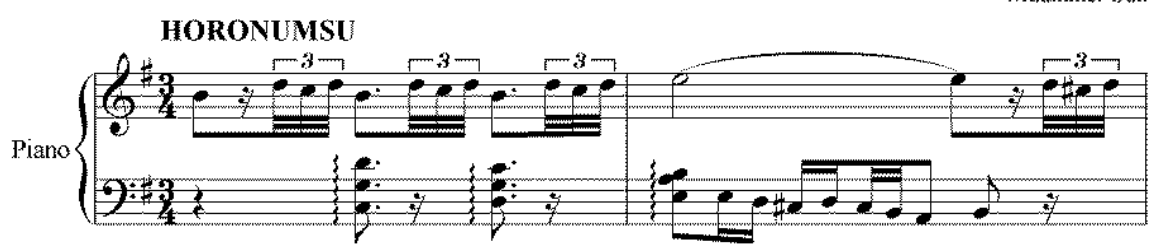

Figure 4: Muammer Sun Yurt Renkleri for Piano, 4. Movement Horonumsu (Yalçın vd. 2012: 785) 


\section{Halay}

Halay from kırikhava genre is a folk dance performed collectively with drum, zurna and sometimes other instruments. It is seen in the composition of the following international Turkish composer.

- Ahmed Adnan Saygun Sivas Düz Halayı for baritone and piano

Traditional Halay sample is shown in Figure 5:

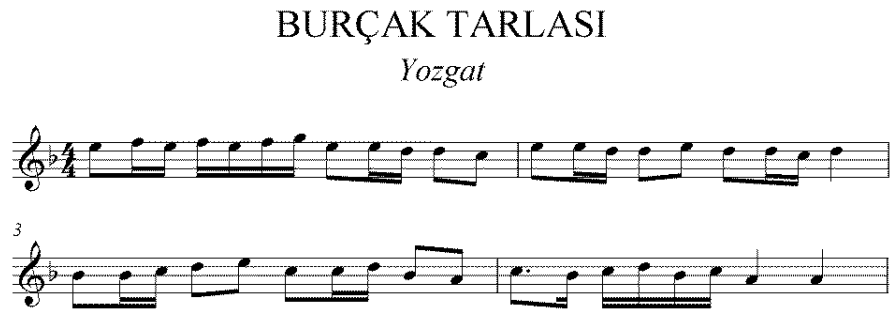

Figure 5: Traditional Halay Sample (baglamist.com, 01.06.2017)

The usage of halay genre by Ahmed Adnan Saygun, one of international Turkish composers, is shown in Figure 6:
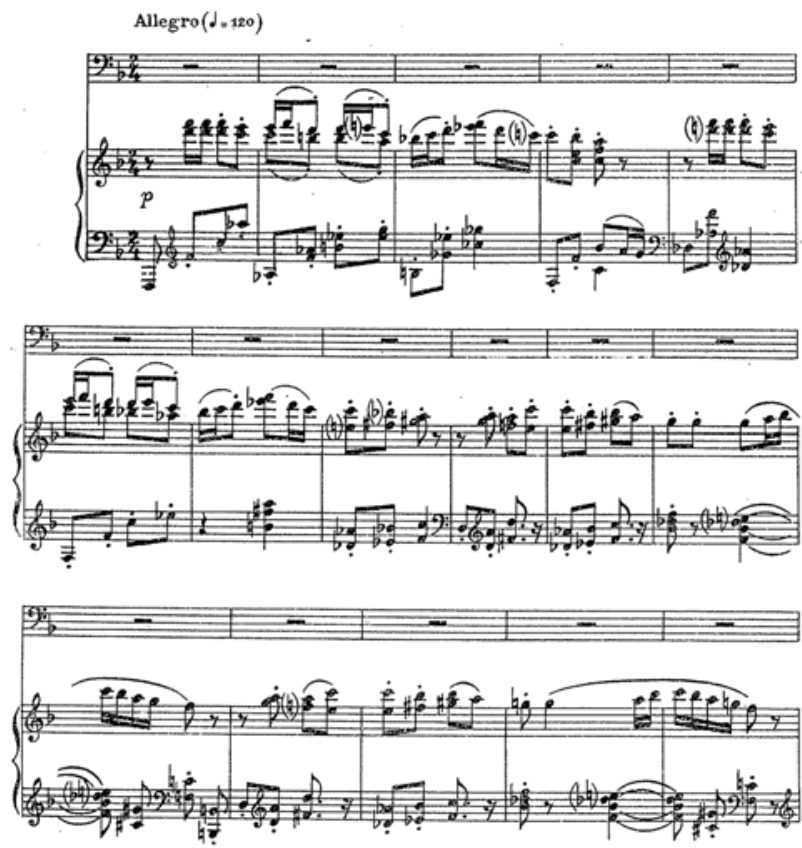

Figure 6: Ahmed Adnan Saygun Sivas Düz Halayı, Üç Türkülük Süit for Baritone and Piano (Devlet Konservatuvarı Yayınları 1955: ?) 


\section{Bar}

Bar from kırıkhava genres takes its place in the composition of the following international Turkish composer.

- Ferit Tüzün Anatolian Suite for orchestra, 6. Movement Bar

Traditional Bar sample is shown in Figure 7:

\section{ATABARI}

\section{Artvin}

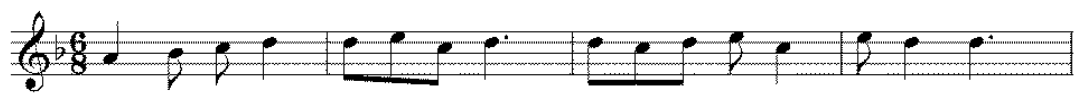

Figure 7: Traditional Bar Sample (turkudostları.net, 01.06.2017)

Bar example of international art music can not be shown due to the copyright law.

\section{Uzun Hava}

Uzun hava is extract of folk music based on recitative performance and singing in free style. It's seen in the compositions of the following composers.

- Özkan Manav Uzun Hava for 8 winds 2 strings

- Kemal İlerici Uzun Hava for violin and piano

- Cenan Akın Uzun Hava for piano

- Muammer Sun Uzun Hava and Kirikhava for piano

Traditional Uzun Hava sample is shown in Figure 8:
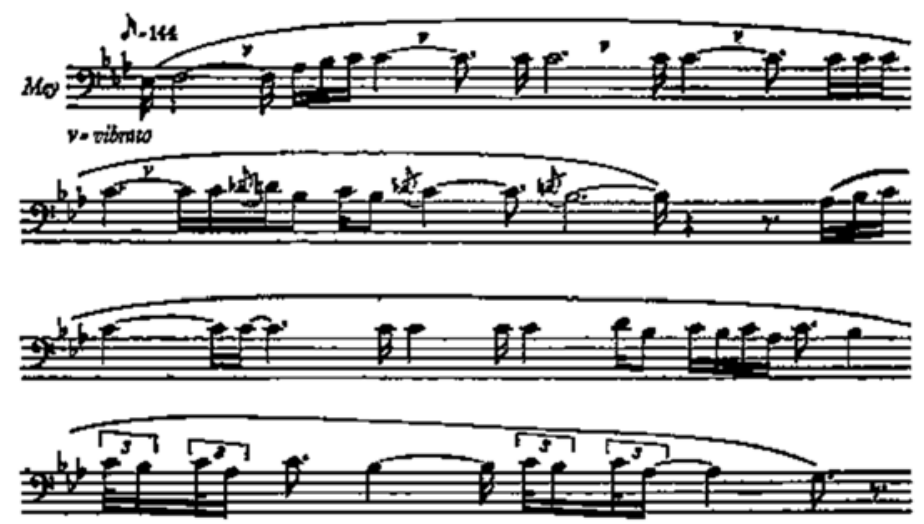

Figure 8: Traditional Uzun Hava Sample (turkudostları.net, 01.06.2017) 
The usage of Uzun Hava genre by Muammer Sun, one of international Turkish composers, is shown in Figure 9:

\section{UZUN HAVA}

Muammer Suat

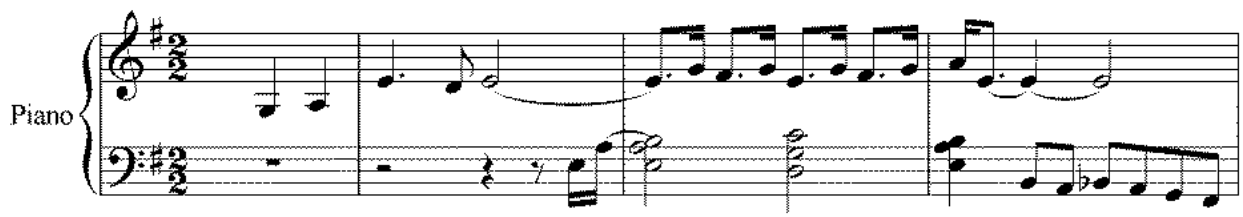

Figure 9: Muammer Sun Uzun Hava for Piano (Yalçın vd. 2012: 775)

\section{Bozlak}

Bozlak is a type of uzun hava genre specific to Western Anatolia and it takes its place in the composition of the following composer.

- Ahmed Adnan Saygun Bozlak for bass and orchestra

Traditional Bozlak sample is shown in Figure 10:

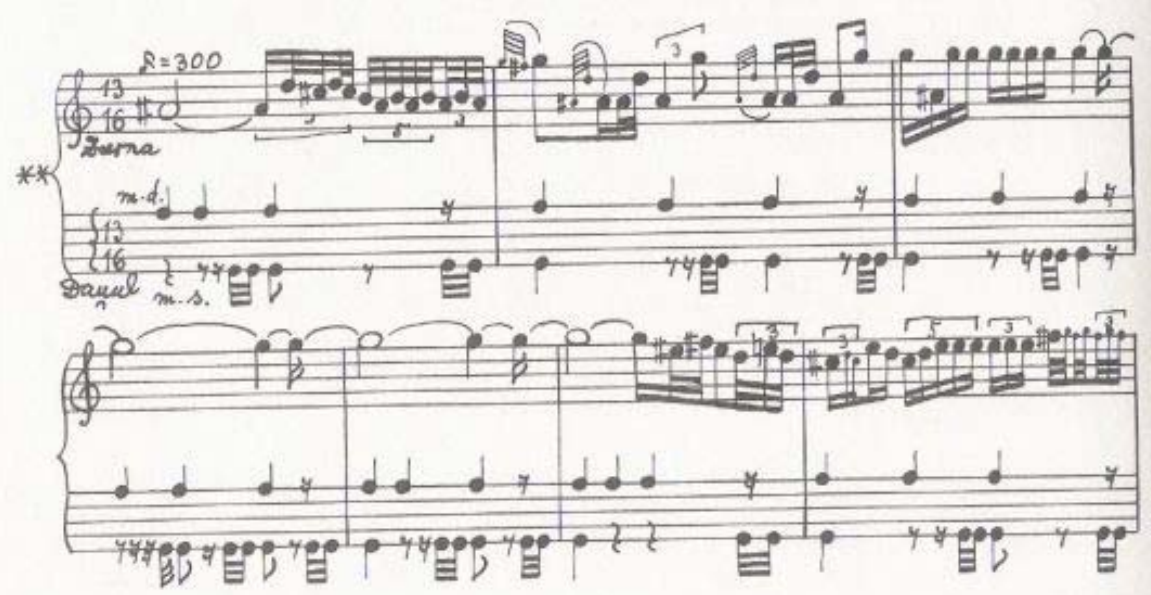

Figure 10: Traditional Bozlak Sample (turkudostları.net, 20.06.2018)

Bozlak example of international art music can not be shown due to the copyright law.

The forms and genres of traditional art music are used in international art music below: 


\section{Mevlid}

Mevlid is the genre of reading a poem which is written by Süleyman Çelebi with melody and it tells the diversity of God and Muhammed his prophet. Mevlid from religious genres takes place in the composition of the following composer.

- Selman Ada Koro, Mevlid Cantata for orchestra, soloists and choir.

Traditional Mevlid sample is shown in Figure 11:

\section{MEVLID}

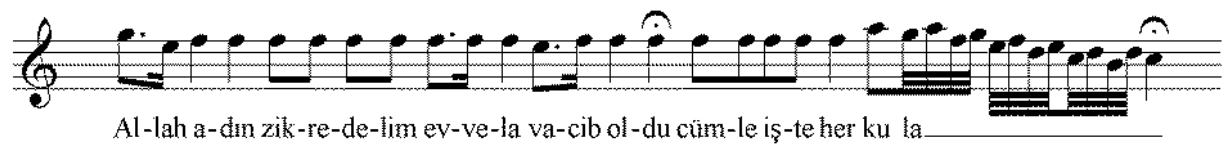

Figure 11: Traditional Mevlid Sample (Akdoğu 1996: 466)

Mevlid example of international art music can not be shown due to the copyright law.

\section{Gazel}

Gazel is an extempore genre performed by human voice without being bound to any usûl. Gazel from non religious genres takes place in the following composers.

- Necil Kazım Akses Bir Divandan Gazel for tenor and orchestra

- Mehmet Nemutlu Güdük Gazel for violin and piano

Traditional Gazel sample is shown in Figure 12:

\section{EY KAMER-İ TAL'ÂT}

\section{Gazel}

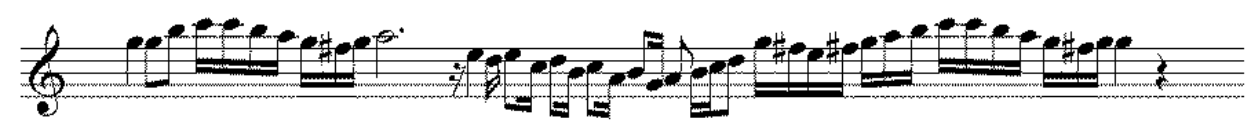

Figure 12: Traditional Gazel Sample (Akdoğu 1996: 289)

Gazel example of international art music can not be shown due to the copyright law. 


\section{Köçekçe}

Köçekçe is a music type formed by the combination of songs and folksongs. Köçekçe which builds bridges between folk music and art music from non religious genres takes its place in the compositions of the following composers.

- Ulvi Cemal Erkin Köçekçe for orchestra

- Selman Ada Köçekçe for piano

- Ekrem Zeki Ün Köçekçe for piano

- Muammer Sun Köçekçemsi for piano; Köçekçe for violoncello; Köçekçe for violin and piano

Traditional Köçekçe sample is shown in Figure 13:

\section{BIR SEVDA GELDİ BAȘIMA}

\section{Köçekçe}

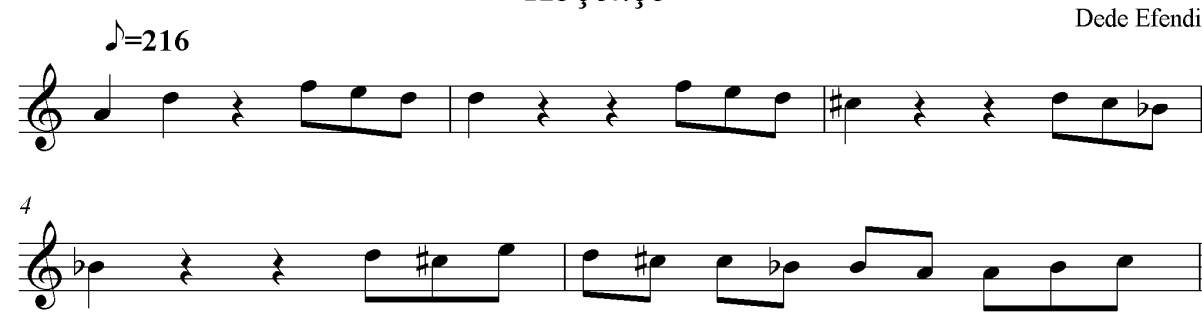

Figure 13: Traditional Köçekçe Sample (turksanatmuzigi.org, 01.06.2017)

The usage of Köçekçe genre by Muammer Sun, one of international Turkish composers, is shown in Figure 14:

\section{KÖÇEKÇEMSI}

Muanduer Sum

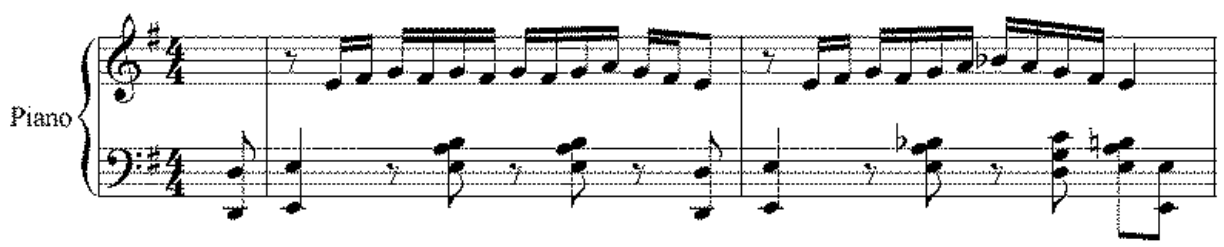

Figure 14: Muammer Sun Köçekçemsi for Piano (Yalçın vd. 2012: 779)

Instrumental music genres of traditional art music in international art music are used in the compositions by the composers below: 


\section{Taksim}

Taksim is an extempore genre of instrumental music which is not bound to any method but bearing all characteristics of maqams. The composers that used taksim in their composers are:

- Hasan Ferid Alnar Concerto for kanun and orchestra end of the first movement kanun taksim

- Özkan Manav Taksim for b flat clarinet

- Ferit Tüzün Çeşmebaşı Bale Suite end of the third movement Taksim

Traditional Taksim sample is shown in Figure 15:

\section{HICAZ TAKSIM}

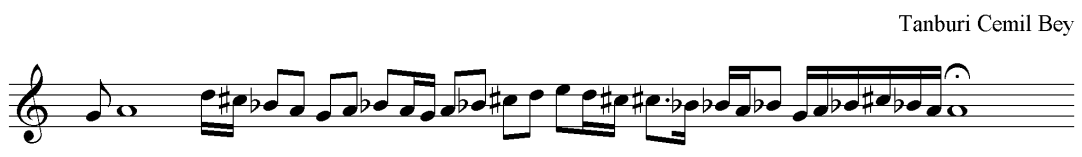

Figure 15: Traditional Taksim Sample (Akdoğu 1996: 288)

The usage of Taksim genre by Hasan Ferid Alnar, one of international Turkish composers, is shown in Figure 16:

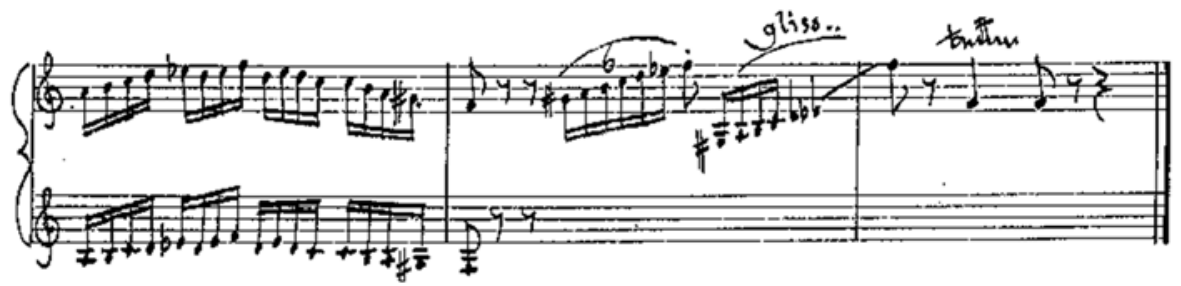

Figure 16: Hasan Ferid Alnar Concerto for Kanun and Orchestra End of the First Movement Kanun Taksim (Altınköprü 2004: 94).

\section{Peşrev}

Peşrev is an instrumental music genre played at the beginning of music. The composers that used Peşrev in their compositions are:

- Hasan Ferid Alnar Concerto for kanun and orchestra, beginning of the first movement; end of the third movement, rast peşrev

- Necdet Levent Concerto for kanun and orchestra, Peşrev; Peşrev for violin and piano

Traditional Peşrev sample is shown in Figure 17: 


\section{FERAHFEZA PEŞREV}

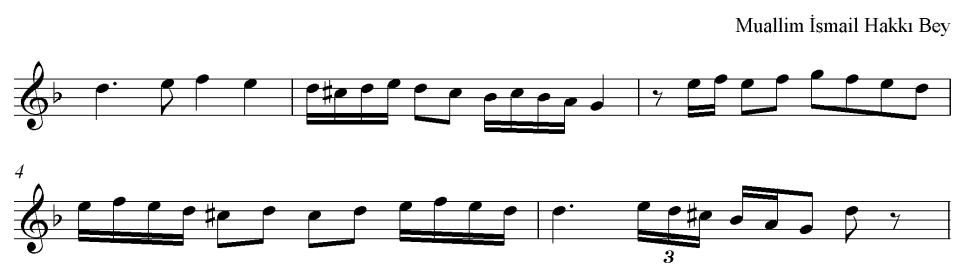

Figure 17: Traditional Peşrev Sample (Akdoğu 1996: 292)

The usage of Peşrev genre by Hasan Ferid Alnar, one of international Turkish composers, is shown in Figure 18:

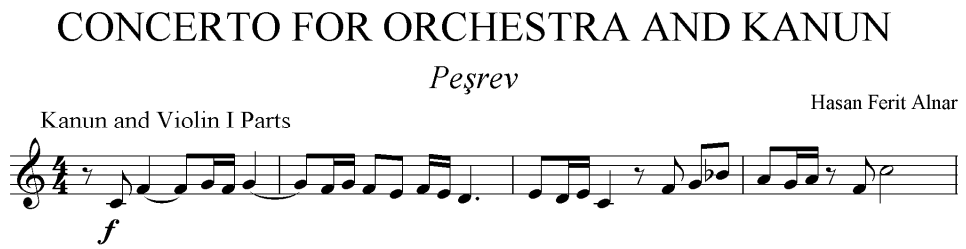

Figure 18: Hasan Ferid Alnar Concerto for Kanun and Orchestra, Beginning of the First Movement I. Violin Part (Aydın 2003: 81).

\section{Saz Semaisi}

Saz Semaisi is a genre of music played in the final part. The composers used saz semaisi in their compositions are: tambur

- Yalçın Tura Hüseyni Saz Semaisi for ney, classical kemençe and

- Necdet Levent Nihavend Saz Semaisi for violin and piano; Ferahnak Semai for orchestra; İki Semaî for violin and piano

- Kemal İlerici Hüseyni Saz Semaisi for string quartet

Traditional Saz Semaisi sample is shown in Figure 19:

\section{FERAHFEZA SAZ SEMAİSI}

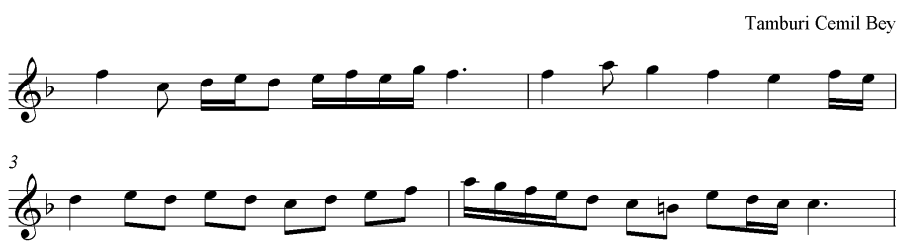

Figure 19: Traditional Saz Semaisi Sample (Akdoğu 1996: 307) 
The usage of Saz Semaisi genre by Necdet Levent, one of international Turkish composers, is shown in Figure 20:

\section{FERAHNAK}

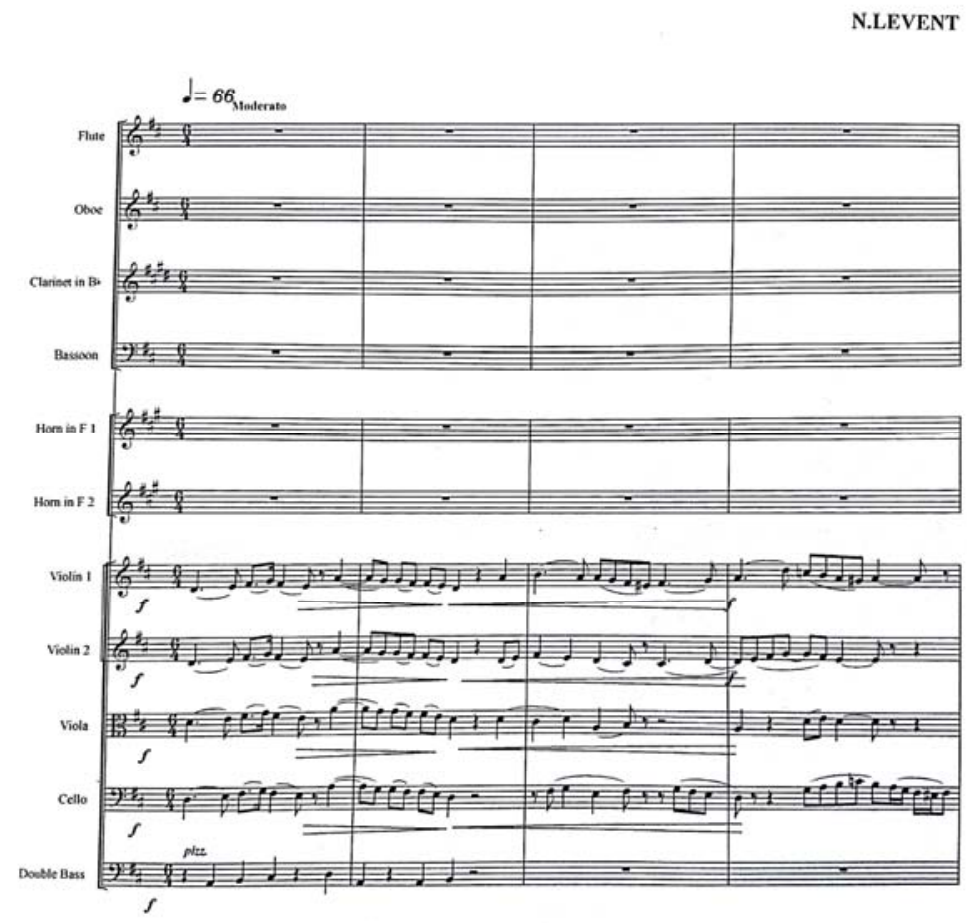

Figure 20: Necdet Levent Ferahnak Saz Semaisi for Orchestra, First Movement (muziklopedi.org, 25.06.2017)

\section{Sirto}

Sirto is a genre played at the end of performance with $2 / 4$ measure. The composer used sirto in his composition is:

- Hasan Ferid Alnar Üç Oyun Havası for orchestra 3. Movement Sirto

Traditional Sirto sample is shown in Figure 21:

\section{NIKRİZ SİRTO}

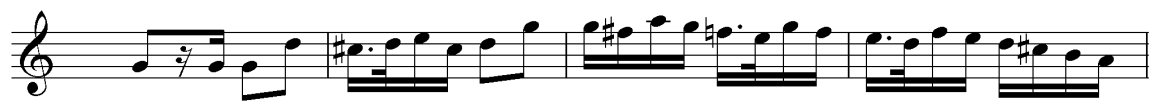

Figure 21: Traditional Sirto Sample (Akdoğu 1996: 328) 
Sirto example of international art music can not be shown due to the copyright law.

\section{Longa}

The following composers used Longa in their compositions are:

- Selman Ada Rhapsodie Nihavend Longa for piano

- Muammer Sun Nihavend Longa for chamber orchestra

Traditional Longa sample is shown in Figure 22:

\section{HISARBUSELIK LONGA}

Santuri Ethem Bey

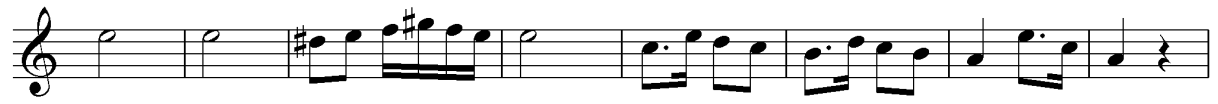

Figure 22: Traditional Longa Sample (Akdoğu 1996: 332)

Longa example of international art music can not be shown due to the copyright law.

\section{Oyun Havası}

Oyun havası is a genre specific to play any kind of play which does not have any certain type but available to perform any kind of dance. The following composers used oyun havasi in their compositions are:

- Hasan Ferid Alnar Üç Oyun Havası for orchestra; Oyun Havaları for piano (Zeybek-Çiftetelli-Sirto)

- Selman Ada Karcığar Oyun Havası for wind quintet

- Yalçın Tura Oyun Havaları for chamber orchestra

- Faik Canselen Oyun Havas1 for piano

- Ferit Tüzün Çeşmebaşı Bale Suite 4. Movement Oyun Havası

- Necil Kazım Akses Çiftetelli Symphonic Dance

Traditional Oyun Havas1 sample is shown in Figure 23: 


\section{NIHAVEND OYUN HAVASI}

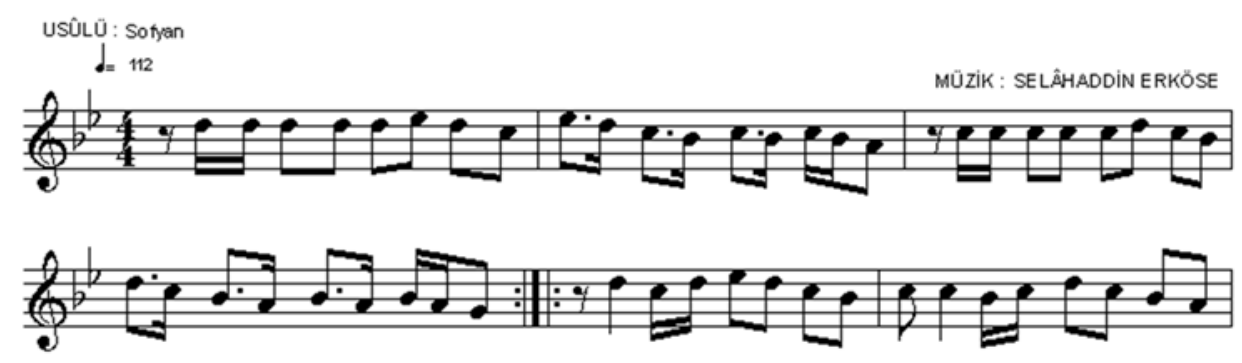

Figure 23: Traditional Oyun Havas1 Sample (projetsm.com,25.06.2017)

Oyun Havası example of international art music can not be shown due to the copyright law.

\section{CONCLUSION}

In the list above, it is seen that traditional genres are used by less number of international Turkish music composers. This may be the reason why some composers are in new music trends or they are grown up in the new music environment. It is thought that the composers using the traditional genres were affected by the national music movement that started in nineteenth century and with the political reasons of foundation of republic and seeking for becoming specific. It is conspicuous that folk music forms and genres are used more than traditional art music forms and genres by Turkish international art music composers. It is observed that art music genres having bridge characteristics are used more. Folk music is used in the early years of the Republic and later it's shown that art music genres are used. During the Republic foundation years only Hasan Ferid Alnar, because since he obtained traditional education, used art music genres. Instead of making national and international music synthesis with maqam structures against Western tonality, it may be a rare but much effective composing method to make synthesis of Western tonality with Turkish traditional form and genres. 


\section{BIBLIOGRAPHY}

Akdoğu, Onur (1996). Türk Müziğinde Türler ve Biçimler. İzmir: Ege Üniversitesi Basımevi.

Altınköprü, Halil (2004). "Cumhuriyet Döneminde Türk Müziğinde Çağdaşlaşma Çalışmaları ve Hasan Ferid Alnar”. Unpublished master's thesis. İzmir: Ege Üniversitesi.

“Atabarı (Bahçası Var Bağı Var)”. http://www.turkudostlari.net/nota.asp?turku=114. Retrieved in June 1, 2017.

Aydın, Yılmaz (2003). Türk Beşleri. Ankara: Müzik Ansiklopedisi Yayınları Şen Matbaası.

“Bir Sevdâ Geldi Başıma - Köçekçe Notası.” https://www.turksanatmuzigi.org/notalarimiz/hicaznotalari/bir-sevda-geldi-basima-kocekce-notasi. Retrieved in June 1, 2017.

"Bozlak". https://www.turkudostlari.net/ezgi.asp?nota=784 Retrieved June 20, 2018.

"Burçak Tarlası (Sabahınan Kalktım) (Halay)".

http://www.baglamist.com/b/burcak-tarlasi-sabahinan-kalktim-halay.html. Retrieved in June 1, 2017.

"Ferahnak". http://www.muziklopedi.org/files/nota/nota_1236806329.pdf. Retrieved in June 25, 2017.

"Nihavend Oyun Havas1". http://projetsm.com/uploads/attachment/20631_v1_1.gif. Retrieved June 25, 2017.

"Oynayın Giz Oynayın (K1z Atlatma Horonu)". http://www.turkuler.com/nota/ezgi_oynayin_kiz_oynayin.html. Retrieved in June 1, 2017.

Özkan, İsmail Hakk1 (2003), Türk Musıkîsi Nazariyatı ve Usûlleri Kudüm Velveleleri. İstanbul: Ötüken Neşriyat A.Ş.

Saygun, Ahmed Adnan (1955). Sivas Düz Halayı Üç Türkülük Süit Op. 23, No 4 Bariton ve Piyano İçin. Ankara: Devlet Konservatuvarı Yayınları.

Sözer, Vural (2005). Müzik Ansiklopedik Sözlük. İstanbul: Remzi Kitabevi A.Ş.

Şenel, Onur (2006). “Ferit Tüzün'ün Çağdaş Türk Besteciliği İçin Önemi”. Unpublished master's thesis. Ankara: Başkent Üniversitesi.

"Uzun Hava". https://www.turkudostlari.net/ezgi.asp?nota=386. Retrieved in June 1, 2017

"Yağcılar Zeybeği". http://www.turkuler.com/nota/ezgi_yagcilar_zeybegi.html Retrieved June 1, 2017.

Yalçın, Gökhan ve Özer Kutluk (2012). "Muammer Sun'un Yurt Renkleri 1. Albümde Yer Alan Piyano Eserlerinin Armonik Analizi," JASSS The Journal of Academic Social Science Studies, 5(7):769-788. 